\title{
＜資料調査報告＞
}

\section{『英和対訳袖珍辞書 $d$ 研究史における勝俣銓吉郎}

遠 藤 智 夫

はじめに

早稲田大学図書館蔵『洋学文庫』は、大槻家旧蔵書・第 4 代図書館長故岡村㔬妾氏 旧蔵書・故勝俣銓吉郎教授旧蔵書などから構成され、蘭学・洋学の第一級資料を多数 含むことが知られている。Cナンバー勝俣旧蔵書の英学資料の中には、本邦初の活字 本英和辞書で稀覱本の誉れの高い『英和対訳袖䂦辞書』文久二年刊初版む含まれてい る。

さて、本稿は、本学会創立40周年記念第41回全国大会（2004年10月31日）での筆者 の口頭発表資料に加筆修正をしたものである。当日の発表は、勝俣銓吉郎が大正15年 に行った British Museum ばりの臨場講演形式の実物教授にあやかろうと、会場校 早稲田大学国際会議場の $\mathrm{OHC}$ という文明の利器を用いて試みたものであったが、本 論考では、『英和対訳袖珍辞書』研究史における勝俣銓吉郎の業績に焦点を絞ってみ た。

氏の英学上の業績については、今さら付け加えることもないが、本邦初の本格的英 和辞典『英和対訳袖珍辞書』についての初めての詳細な紹介「最初の英和対訳字書」 を、今から、90年も前に『英語青年』に発表した氏の業績を、日米和親条約締結百年 記念の年で、また本学会創立40周年の節目の年に、ふりかえることができた記念に、 発表の詳細を残すことも意味無しとは言えまい。

大正三年に、勝俣銓吉郎が『英語青年』に 2 回にわたっって発表した「最初の英和対 訳字書」の中で、「文久版は僅に二百部しか印刷しなかった」と、初めて発行部数に ふれたことは注目に値しよう。筆者は、大梘文彦論文との比較調查を試みながら、初 版の発行部数について、調査に基づく若干の考察を加えることにする。 


\section{英 学 史 研 究 第38号}

\section{I 勝俣銓吉郎年譜}

明治 5 年（1872）11月18日、神奈川県足柄下郡に生まれる。生家は旅館業であったが、 家産傾き、少年期より苦学する。本名銓吉、通称銓吉郎。

明治18年（1885）横浜郵便局書記と成り、earn and learn の生活が始まる。この間、 山手百二十番にあったミッション・スクール横浜英和学校に通学、 西洋人より、英語の手ほどきを受ける。

明治29年（1896）上京、国民英学会に入学、岡倉由三郎等に影響を受ける。氏が受け た専門教育は、この1年足らずで、あとは一切独学であった。

明治30年 (1897) Japan Times 社創立と同時に入社。

明治31年（1898）『青年（The Rising Generation)』(『英語青年』の前身）第 1 号を、 武信由太郎編集長と二人で編集、Japan Times 社から発行。

[語録「私のほんとうの母校は、ジャパン・タイムス社ですよ。」

明治34年（1901）東京府立第四中学校教諭心得。

[語録］「英字新聞の記者から、英語の先生に転向した。how は手 に入ったが、頭が空っぽで、whatの方がそしかったから、大いに 読書して思想力を養抢うと思った。」

明治35年（1902）三井鉱山合名会社に入社、団环黁専務理事の英文秘書となる。

明治36年 (1903) 八ワード・スワン（Howard Swan）・勝俣銓吉郎共著『応用英和 新辞典』発行。

明治39年 (1906) 早稲田大学講師。

明治42年（1909）神田乃武・南日恒太郎共編『英和双解熟語大辞典』の発案・材料収 集を行う(Prefaceに、記載されている)。

明治44年 (1911) 早稲田大学教授に昇任。『英和例解要語大辞典』出版。

[語録] 'A teacher of English should be a cultivator of love of language, love of knowledge, and love of Man.'

[語録]「編者は過去二十余年、外に在っては、ポケットに notebook を絶やさず、家に在っては左右に手帳と鉛筆とを離さず、英 語研究の資料となる見聞事項の採録を怠らなかった。note-book habit の産物である。」 
大正 3 年（1914）「古い会話書」を『英語青年』第三十巻第七号・第八号・第九号に 発表。「最初の英和対訳字書」を『英語青年』第三十二巻第一号・ 第二号に発表。

大正10年（1921）「日本欧化史の片影＝徳川時代に於ける英語研究」を『我等』第三 巻第十一号・第十二号に発表。

昭和11年（1936）『日本英学小史』を研究社から出版。66歳。

昭和14年（1939）『英和活用大辞典』を研究社から出版。

[語録]「早稲田で私の教えた英語は、その性質において他の先生 と違った点が一つある。他の先生の英語は、学校で「習った英語」 を教えるのに対し、私のは実社会で「使った英語」を教えたのであ る。 learnした英語と use した英語、すなわち language と speech の違いがあった。」

昭和15年 (1940)「徳川時代の洋書」を『学鎧』44巻 4 号に発表。

昭和18年 (1943) 早稲田大学教授停年退職。

昭和19年（1944）早稲田大学名誉教授の称号を䁬られる。(早稲田大学勤続38年) 昭和25年（1950）立正大学文学部教授。77歳。

昭和26年（1951）富士短期大学初代学長。

昭和29年（1954）『新和英大辞典』第 3 版を研究社加出版。（第 2 版は、武信由太郎 編）「日本で最初の英和辞典」を月報『辞書』第二号、研究社に発 表。

昭和32年（1957）英語学の研究業績により、我が国英学者として、初めて、紫綬褒章 を授与された。

なお、「倠章の記」には、「勝俣銓吉 早くから英語学の研究並び に日本語彙の集成に精進し英和活用大辞典及び新和英大辞典を刊行 してょくその業績を残しわが国英語学の進展に貢献し事績まことに 著明であるよって裹章条例により紫綬集章を睗って表彰せられた。 昭和三十二年十一月三日 内閣総理大臣 岸 信介・・第一一 六号」とある。

昭和33年（1958）『新英和活用大辞典』を研究社から出版。85歳。

[語録]「むう5 年、91歳までは生きて、さらに、三冊の辞書編集 を終わらせたい。」 
昭和34年（1959）9月22日、逝去。86歳。遺言により、早䄶田大学区書館へ、「勝俣 文庫」納入。

「英学者の生厓一勝俣銓吉郎翁追悼」か『英語青年』第百五巻、第 十二号 pp 22-40に掲載される。

昭和46年（1971）早樎田大学図書館編『羊学文庫目録〔稿〕』、勝俣旧蔵書か記載 され、同図書館て、届出制て閲覧可能となる。

以上は、『英語青年』第百五巻、第十二号、昭和34（1959）12 1 「英学者の生崕一 勝俣銓吉郎翁追悼」中の上光磯吉「勝俣銓吉郎永略伝」をもとに、増田綱・矢吹勝二・ 増田貢の追悼文から [語録］を補充し、勝俣氏の英学関係発表㖮文・勝俣旧蔵書の件 なとを追加した。

\section{II 「英和対訳袖珍辞書」に初めて言及した大槻文彦論文}

1 大槻文彦「和蘭字典文典の記述起原」『史学雑志』第九編第三号、明冶31（1898） 3 10、pp $12-13$

[英学の興るに及ひ英和対訳辞書の必用起れること㖮を待たす］1［是に於て堀

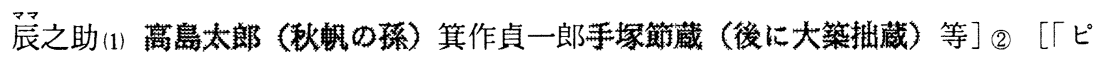
カルト」の英蘭対訳辞書を採りて（「ホムホフ」の英蘭対訳辞書の舶来は是より後 なりと云ふ）］(3 [蘭語を削りて和蘭字彙中なる和訳語を当てて英和対呎忽ち成り て］(4) [文久二年十二月］(5)［幕府の開成所上り発行せり］(6)［鉛製估字を用いて］(7) [雁皮紙の］８［両面招にて］(［横本西佯経一冊なり］@「右の開成所版の辞書、始 めは一冊の価二両程なりしに英学の勃興するに随ひて需要極めて多くなりて後には 一冊の転売拾両乃至武拾両にも及へり」(10 (2)

2 大槻文彦『復軒雑纂」、明佁35年（1902）、p 217 同上。

3 大柣文彦『箕作麟詳君伝』明佁40年（1907）、p 20 


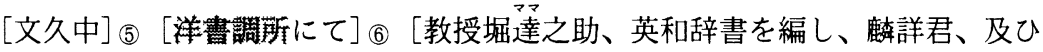
千村五郎、竹原雄四郎、渡辺欣三等、これを補助して、] (2) [文久二年刊行せり] (5) [是れ我か邦、英和対訳辞書の嚆矢なり、四「尋て（筆者主 ついて）、堀越亀之助、 （愛国）これを校正増補して、慶応二年再刊す、] 13 「後の英和辞書率的（筆者主 お おむね）これに拠れり、」凹

\section{III 『英和対訳袖珍辞書」を詳細紹介した勝俣論文}

1 「最初の英和対訳字書」『英語青年』第三十二巻第一号、大正 3 年（1914）10 1、 p 19

‥一体日本の英和字書なるものは何てあって、誰か編纂し、とうして出来た あのてあらうか・・・僕は数年前から英学源流の研究に興味を持ち始め自然この問 題にも住意を払って居たかまた十分の研究か届かないのて不満足てはあるか免に角 古老の直話やら群書の歩猟やらて多少䌅まった知識か得られたのてあるから本誌の 一隅を拝借して同好の士の一粲（筆者主 いっさん）に供する次第てある。

『英和対訳袖珍辞書』

[これか即ち我邦に於ける板行英和字書の魁（筆者住 さきかけ）て］(3) (3) 英語て は A Pocket Dictionary of the English and Japanese Language としてある。 出版年月は [ペルリ艦隊か浦賀の門を敲いてから十年後］(1)の［文久二年十二月 て］(5) [当時每内唯一の官立外国語学校蕃書调所て編纂されたものて］(6) (4) あるか ら言はは旧政府から新日本への置土産てある。[編箱に関係した人々は序文にも歌 ってある通り同所（序文には the School of European Languages としてある） の教官堀辰之助西周助 (西周)、千村五郎、竹原勇四郎、箕作貞一郎 (麟祥) 等 て] (2) (5) 全然日本人の手に成ったものてある。

堀 辰之助

この字書（以下便宜上「開成所辞書」と云ふ）の編纂に最も力を尽されたのは堀 辰之助て、もと長崎の和蘭通詞出身て.. 弘化二年といふに俌賀詰めを命せられた 人て・.・ペルリか来航の時にも氏は通訳に当ったのて「通弁骨折り候訳を以って御 褒美」として銀拾五枚頂戴している。・.安政六年十月に蕃所調所の頭取古賀謹一 郎の周旋て…啁所の教員に採用され専ら英語の教授に当り傍ら英和字書の編篦に 
英学 史研 究 第38号

従事することとなった。字書の編纂は文久元年に業成り同八月に賞典授与のことが あった。

蕃所調所

\section{「開成所字書」の種本}

…[「開成所」字書の種本といふのは和蘭版の英蘭蘭英小字典で A New Pocket Dictionary of the English-Dutch and Dutch-English Languages といって H.Picard といふ人の編纂したものである。(3) 種本となったのは1873版で、堀の手 沢本は現に大阪の小山健三氏が珍蔵せられる。同氏よりの来翰に依ると堀は舶載の 当時米数俵之交換せられたあのださうである。其頃は洋書を手に入れるといふこと は仲々手易い訳のものでなかったのである。

2.「最初の英和対訳字書」『英語青年』第三十二巻第二号、大正 3 年 (1914). 10.15、 pp. 56-57

\section{(其二)}

装幀と印刷

[「開成所字書」の製本は洋装で大サは六寸三分の五寸二分といふ枕本形の横本 である。］10（用紙は鳥の子で］８頁数は九百九十八頁、語数は一万七千から二万迄 である。[印刷は極めて特色のあるもので英字の方は鉛製活字を用い訳語の漢字片 仮名は一頁一枚の木版で］(7) [両面摺になって居る。］(9)印刷は鮮明で我邦初期の横 文印刷としては大に誇るに足るものである。当時蕃書調所には「活字方」といふす のがあって洋式の手引印刷機と横文活字とが備へてあった。これは和蘭から幕府に 献上した品だといふことである。榊令輔と云って今の榊医学博士の厳君に当る人が この横文印刷の主任をやっていた。・..仲々器用な人で此人が卑に角蕃所調所の横 文印刷を自身に引受け「開成所字書」・.等を印刷されたのである。之が本邦西洋 式印刷の濫觞であらう。

内容

前にも述べた通り対訳字書は [ピカールトの英蘭蘭英小字典を種本としその英蘭 の部の英語を其儘印刷しこれに当時既に世に流布していた蘭和字書（「ハルマ和解」 とか「和蘭字彙」とか「訳鍵」とかいふ）を参考して各英語に添へたる蘭語をこれ 
等の字書に依って邦語に転しこれをそれそれ英語に付加したものてある】(4)からて あなく和蘭か媒酌人となって日英か語学の上に於いて婚礼をやった様になっている。 かういふ風にして出来上かったのてあるし何しろ草分けの仕事てあるから完全はあ とより期せられないのてある。東西の思想言語の形式か甚しく盚隔していた当時に 其顛度しをするといふことは今日より幾倍も困難な仕事てあったのてある。併し... 大成功て吾人は編篣に力を竭（筆者住つく）された当時の英学者に対し大に敬意を 表するものてある。…訳の方から言へは第一名前の pocket からして可笑なむのた。 種本 Picard は造かに pocket size てあるか「開成所字書」の方は六寸、五寸といふ 枕本てあるから懐へは這入るたらうか pocket へは到底入れられ代物て世に「枕 字書」と云はれる通り立哌に枕の代用になる位な奴てある。・.時代色の顕れた訳 語や、訳語未定の為め長たらしく説明的にやった訳なと取交せて次に、

…fire-works 日技、post-office 飛脚屋、rallway 火輪車/道、library 書物 $\exists$ 集 メ置ク所、(以上は総て再版より摘記せるもの)(6)

訂正再版

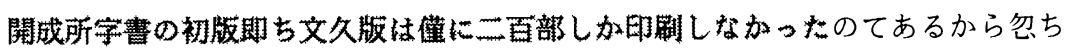
売切となり [五年後の慶応二年に再版か発行された。この再版の訂正者は堀越愛国 翁て] 今に存命され板橋在志村の村居に悠々自適余生を送られて居る。本年八十 歳の高齢者てある。訂正に当られたのは翁か開成所の教官をせられて居た時て翁の 直話に依ると改刻に入費を多く費（か）けたくないから余り手を入れ奴にとの 註文て一頁に一二個所の割合て訂正を加へたのたさうてある。当時幕府の金庫は大 分疲弊して居たのてこの有用な出版事業にさへ十分の支出を惜んたのてある。訂正 再版といふのは初版の板木に改正の簓所丈填木をしたのてある。・..初版再版共に 刊行部数か少ないのと一方ては [英語研究か旭日の勢を以って日に日に盛になった のて最初武両程てあった「開成所字書」か後には十両廿両といふ高値て転売される やうになった。①...この再版は千部印刷をしたか・..間もなく絶板となってしまっ た。そこて開成所へ御出入の材木商蔵田屋清右衛門といふ人か許を得て全部木版に して慶応三年に売出し大分储けたさうた。・・新陳代謝の頻繁な新日本の初期のこ とてあるから「開成所字書」はやかて其尽くすへき役目を果し一時は学者の宝典之 して珍重された「枕字書」あ数年の後不用になったのてあだら貴されて紙屑屋の手 に度り紙として使はれ又は今日古電話帳か使はれるやうに八百屋等の店売覚帳とし て用いられた為め今日ては大部品少になって居る。蔵田版の方はまた折々古本屋て 
英 学 史 研 究 第38号

見ることかあるか慶応二年版殊に文久の初版になると極めて稀てある。(7) 薩摩字書 - •

3 『日本欧化史の片影＝德川時代に於ける英語研究』『我等』第三巻、第十二号、我 等社、大正10年（1921）. 12

\section{一一 最初の板本英和字書}

…開国に付随して英語研究の必要か切実に感せられるやうになったのて、英 和字典の出版を要望する声か大分高まった。そこて開成所てその編著に従事するこ とになって、文久二年に業を終へている。[これか明佁以降出版された幾百の英和字 典の母てある。] 書名は「英和対訳袖珍辞書」て英語ては A pocket Dictionary of the English and Japanese Language としてある。・・用紙は普通鸟の子て あるか、䍩紙に印刷したものと見へて、現に僕の所蔵しているものは洋紙てあ

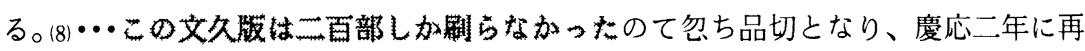
版か発行された。これは堀越爱国永かその訂正をせられた。・・開成所の字書に就 ては数年前詳細事項を「英語青年」誌上て発表したから、その方に譲って茲所ては 略説に止める。

4 『日本英学小史』研究社、昭和11年（1936）1

IV 英学勃興時代 11 英和辞書の刊行

徳川時代に於ける英語に関する最大著作は、何と言っても、開成所出版の「英和 対訳袖珍辞書」てある。その編纂主任は前記の長崎通詞堀達之助てある。台本とし て使用したのは、Picard の英蘭辞書てあるか、当時堀の英語の力は大したものて はなかったのてあるから、結局既に刊行されていた蘭和辞書等を参考して英語に配 するといったやうな方法て完成したものてあらうと想像する。それにしても、我よ り古を作すといふ開山の仕事てあるから、その労力は多大なものてあったことは勿 論てある。この開成所辞書は文久二年に刊行されたものて、語数は凡そ二万位。普 通は島の子紙稀に洋紙の両面に印刷してある。今日から言ふと版式か一寸異なって いて面白い。英字の方は、鉛製佸字て、訳の方は一頁一個の木版といふ取合せになっ 


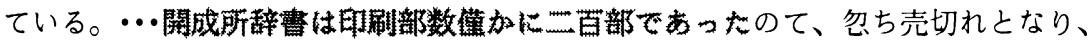
堀越愛国の再版か慶応二年に発行された。・.開成所辞書のことも、少しく精しく 解説を加ふへきてあるか、これに就ては大正三年の「英語青年」掲載の「最初の英 和対訳辞書」と題する拙稿に詳細記述してあるから、茲には略する。

5 「日本て最初の英和辞典」『辞書』月報（11月 1日）、研究社、昭和29年（1954）11

我か国最初の英和辞典「英和対訳袖珍辞書」・・蕃所調所て編纂され、出版 されたのは、今からさっと九十年前文久二年十二月のことて、ペルリか米国艦隊を 率いて俌賀の門を敲いてから十年後のことてある。・・この字書の編箱に・・最も骨 を折ったのは堀辰之助てある。・・彼は・・ペルリか来航した折に、その通訳に当り 「通弁骨折り候訳を以て御集美」として銀十五枚を頂戴しているところを見ると有

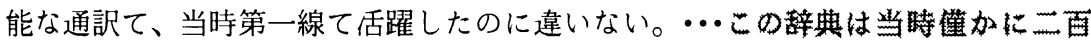
部し加践られ加ったのて、発売後忽ち売切れてしまい、燎原の火の如き勢をむっ て広まりつつあった、英学研究埶の曷望を䒼たすことか出来なかった。そこて、・.・ 五年後の慶応二年にその再版か発売された。・..時・・英学徒の宝典と珍重された 『開成所字書』も・・命日ては古本屋を魚っても减多に手に入らない珍本となってし まった。初版は万という高価ものになっている。

以上、『英和対訳袖珍辞書』にふれた大梘論文 3 本と勝俣論文 5 本を調查検討して きたか、勝俣論文ては、一貫して、初版は僅かに二百部しか印刷されなかったことか 述へられている。そして、大正 3 年『英語青年』掲載の「最初の英和対訳字書」か、 初版の発行部数にふれた最初の論文てあったことを、ここて確認しておきたい。

\section{IV 発行部数についての若干の考察}

\section{1 東京女子大学区書館蔵本末尾の抹,同印からの推定}

東京女子大学図書館蔵『英和対訳袖珍辞書』初版の本文最終ペーノにイノクかしみ ていて末尾しか解読てきない朱方印か見られるか、（）図版 [1]）、筆者か、1999年 の 1 月に、早䄸田大学図書館特別資料室ての資料閲覧中に、たまたま同席した櫻井豪 人会員 (当時、名古屋大学大学院生、現茨城大学) 加、「開成所刊行」 ‘小型朱印” 
英 学 史 研 究 第38号

（＼cjkstart図版 [2]）の存在のご教示を受け、『西洋武功美談』(Leesboek voor de Scholen …1858年) (早稲田大学図書館蔵) の本文最終ページ右上押捺の同印との比較調查 の結果、横幅および最後の「行」の字形が完全に一致した。東京女子大学図書館蔵本 『英和対訳袖珍辞書』最終ページのインクで抹消されたような印は、その向きが気に なったが、訳語の和語の行の向きに合わせて捺印したと考えられよう。

この「開成所刊行」小型朱印について、櫻井豪人「開成所刊行」の朱印と開成所 刊行物」『汲古』第35号、平成11年（1999）、pp. 19-20からの引用を掲げておく。

$\lceil\cdots$ 小型朱印はほぼ慶応元（1865）年以前の刊行物の巻末に捺され、慶応二年以降 の刊行物にはそれに取って代わるように大型朱印が掩されている。小型朱印は...開成 所と改称された文久 3 （1863）年8月以降であるはずだが、実際にはそれ以前に刊行 された資料にも捺されていることがある。‥開成所刊行」の朱印が捺されているこ との解釈として…初印から数年を経た後の開成所時代の後印本であったと考える方が 自然であろう。」

洋書調所が開成所と改名したのは文久 3 年 8 月のことだから、『英和対訳袖珍辞書』 に「開成所刊行」印の押捺のあるあのがあるとなれば、「初版第 2 刷」（たとえば、文 久 3 年開成所刊）が存在したとの推定む可能となる。

\section{2. 杉本つとむ『翻訳日本語辞典』昭和51年（1981）解説の推定}

初版は、Bの部の Blissfully から Blockhead（pp. 80-81）までが欠落していること が、知られているが、東京女子大学図書館蔵本では、本文の p. 80 と p. 81 の間に 1 葉 があって、この欠落部分が印刷されて補われているのである。「同じ文久 2 年の<初 版本>です、この部分が印刷され片面刷りで製本されたものが存在したかもしれない。」 杉本つとむ『翻訳日本語辞典』解説 p. 716とも関連し、初版の印刷部数は、勝俣銓吉 郎が、堀越愛国翁からの直話で聞きだしたと思われる200部より、多かった可能性が 残されたと考えられよう。

\section{おわりに}

ここで、勝俣銓吉郎の英学史料収集についてのエピンードを紹介する。

勝俣銓吉郎追悼号となった『英語青年』第百五巻、第十二号、昭和34年（1959）、 12.1、p. 30掲載の竹村 覚「日本英学史と勝俣先生」という一文には、次のように 


\section{『英和対訳袖珍辞書』研究史における勝俣鋥吉郎}

書かれている。

先生の蒐集は、まことに徹底したもので、・・たとえば、月給をお貪いになると、 さっそく早稲田鶴巻町あたりの古本屋に、つぎつぎと借金を払われ、帰宅した時に は、月給袋は、ほとんど空っぽになっていたことも、度々あったということである。 …こうして先生が集められた資料や文献は、実に貴重なものばかりで、英学史研 究家は、かならず先生の門を吒かなければ、本当の研究が出来ない有様であった。・・ ・勝俣先生は、日頃よく、「教師の仕事は、種蒔きである」と言われていたが、・・ 私が、『日本英学発達史』を出版した時、次のような歌を作って下さった。

よき土に落ちよとまきし種ひとつ

花さきみのる秋にあふかな

竹村 覚氏同様筆者も、勝俣旧蔵書特に、勝俣旧蔵『英和対訳袖珍辞書』各版の 恩恵に深謝しつつ、「花さきみのる秋」を、氏に早く「あわせなくては」と思う次 第である。

\section{[注]}

(1) 『日本教育資料』七、文部大臣官房報告課、明治25年（1892）、p. 666には、「文久元年・・○八月・・ ・4九日... 英字書成業/賞典アリ此字書ヨ成ス二八堀達之助尤モ力ヨ労スト云」とあり、正しい 漢字で「達之助」と書かれている。

(2) ここで、(1)〜11のような数字で示した部分は、後出の勝俣論文と比較調查した部分であり、勝 俣論文の同様事項の記述ととくと比較されたい。

(3) 勝俣銓吉郎が大正 3 年に『英語青年』に発表した論文によって、『英和対訳袖珍辞書』が、活字 印刷による本邦最初の英和辞典である旨、本邦英語界に詳細周知されることになった。

(4) 大柣「和蘭字典文典の記述起原」で「開成所」大柣『箕作麟詳君伝』で「洋書調所」、勝俣論 文で「蕃書調所」と三者三樣の記述だが、「洋書調所」が正しい。

(5) 大柣文彦は、堀の協力者として、『英和対訳袖珍辞書』のPREFACEに名の載っていない高島 太郎・手塚節蔵および渡辺欣三の 3 名をあげている。この中で、渡辺欣三は、箕作麟詳の門人渡 部(辺)一郎(温)と同一人物かと推定されるが、まだ確証はない。

(6)「総て再版より摘記」の注により、勝俣は、大正 3 年の10月には、まだ、初版は入手していなかっ たことがわかる。また、勝俣「日本欧化史の片影」『我等』第 3 巻第12号、大正10年（1921）12月 に、「…現に僕の所蔵しているものは洋紙である。‥」p. 350と書かれてあり、大正10年には初版 を入手していたことになる。そして、その初版は、遺言により、勝俣没後、早稲田大学図書館蔵 となり、すでに、岡村千曳氏により、早稲田大学図書館蔵となっていた静岡・加藤則有旧蔵の初 版と合わせて 2 冊の初版を蔵することになり、早稲田大学図書館は、『英和対訳袖珍辞書』調查研 


\section{英 学 史 研 究 第38号}

究に不可欠の場となった。

(7) 豊田賽『日本英学史の研究』昭和14年（1939）に、「・私の知っている範囲では、大槻家と勝 俣銓吉郎氏、及び尾佐竹博士が所有されている。よ、その稀覯本ぶりが紹介されたが、現在、海 外に 2 本、国内に15本、計17本の現存が確認されている。堀孝彦・遠藤智夫『《英和対訳袖珍辞 書》の遍歴一目で見る現存初版15本』平成11年 (1999)、遠藤智夫・堀孝彦「発掘、第16本目! 『英和対訳袖珍辞書』初版」『辞游 file』No.6、平成12年（2000）、および遠藤智夫「牧野富太郎之 『英和対訳袖珍辞書』」英学史研究』第36号、平成15年（2003）参照。

(8) 本学会の堀孝彦会員と筆者による調査では、現存初版17本のうち、洋紙に印刷されているもの は、この勝俣旧蔵初版 1 本だけである。洋紙の入手は困難だったはずで、この 1 本は、特別な意 味を持つものとも考えられる。
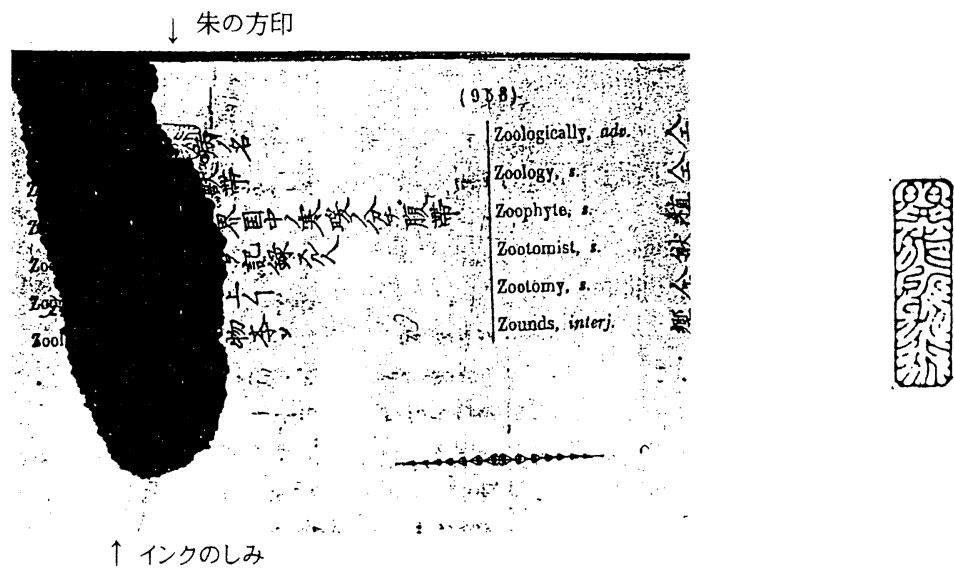

図版 [1] 東京女子大学蔵本末尾の抹消印

図版 [2]「開成所刊行」小型朱印 


\section{What did Prof. Senkichiro Katsumata Contribute to the Study of 『英和対訳袖珍辞書』=A Pocket Dictionary of the English and Japanese Language (sic)?}

\section{Tomo-o ENDO}

This report is based on a reading, by the writer, which took place at our Society's 41st national meeting on 31st October, 2004. The year 2004 was a special year for both our Society and Japan as it jointly marked the 40th anniversary of the foundation of our Society and the 150th anniversary of the conclusion of the U.S.-Japan Peace Treaty in the Edo era. This memorable meeting was held at the International Conference Hall at Waseda University, which has had close links to English Language studies in Japan. As one of the main themes of the meeting was English Language studies at Waseda University, the writer read a paper on the late Prof. Katsumata during his time at Waseda University and his close study of 『英和対訳袖珍辞書』.

In 1914, Professor Katsumata, a famous scholar and teacher of English, contributed an article 'On the first Dictionary of the English and Japanese Languages' to『英語青年』=THE RISING GENERATION, the well-known magazine for English literature and education. By making a comparison between the treatises of Dr. Fumihiko Otsuki and Prof. Katsumata, the writer explicitly points out that in the article contributed by Prof. Katsumata to 'THE RISING GENERATION', the fact was revealed for the first time that only two hundred copies of the first edition of 『英和対訳袖珍辞書』were printed in 1862 .

The writer also indicates the probability of the second printing of the first edition of『英和対訳袖珍辞書』. 